\title{
The 1964 Great Alaska Earthquake and Tsunamis-A Modern Perspective and Enduring Legacies
}

\section{Introduction}

The magnitude 9.2 Great Alaska

Earthquake, which struck south-central Alaska at 5:36 p.m. on Friday, March 27, 1964, is the largest recorded earthquake in U.S. history and the second-largest earthquake recorded with modern instruments. The earthquake was felt throughout most of mainland Alaska, as far west as Dutch Harbor in the Aleutian Islands 800 miles away from Anchorage, and at Seattle, Washington, more than 1,200 miles to the southeast of the fault rupture, where the Space Needle swayed perceptibly. The earthquake caused rivers, lakes, and other waterways to slosh as far away as the coasts of Texas and Louisiana. Water-level recorders in 47 states - the entire
Nation except for Connecticut, Delaware, and Rhode Island - registered the earthquake. It was so large that it caused the entire Earth to ring like a bell: vibrations that were among the first of their kind ever recorded by modern instruments. The Great Alaska Earthquake spawned thousands of lesser aftershocks and hundreds of damaging landslides, submarine slumps, and other ground failures. Alaska's largest city, Anchorage, located west of the fault rupture, sustained heavy property damage. Tsunamis produced by the earthquake resulted in deaths and damage as far away as Oregon and California. Altogether the earthquake and subsequent tsunamis caused 129 fatalities and an estimated $\$ 2.3$ billion in property losses (in 2013 dollars).
Most of the population of Alaska and its major transportation routes, ports, and infrastructure lie near the eastern segment of the Aleutian Trench that ruptured in the 1964 earthquake. Although the Great Alaska Earthquake was tragic because of the loss of life and property, it provided a wealth of data about subductionzone earthquakes and the hazards they pose.

The leap in scientific understanding that followed the 1964 earthquake has led to major breakthroughs in earth science research worldwide over the past half century. This fact sheet commemorates the Great Alaska Earthquake and examines the advances in knowledge and technology that have helped to improve earthquake preparation and response both in Alaska and around the world.

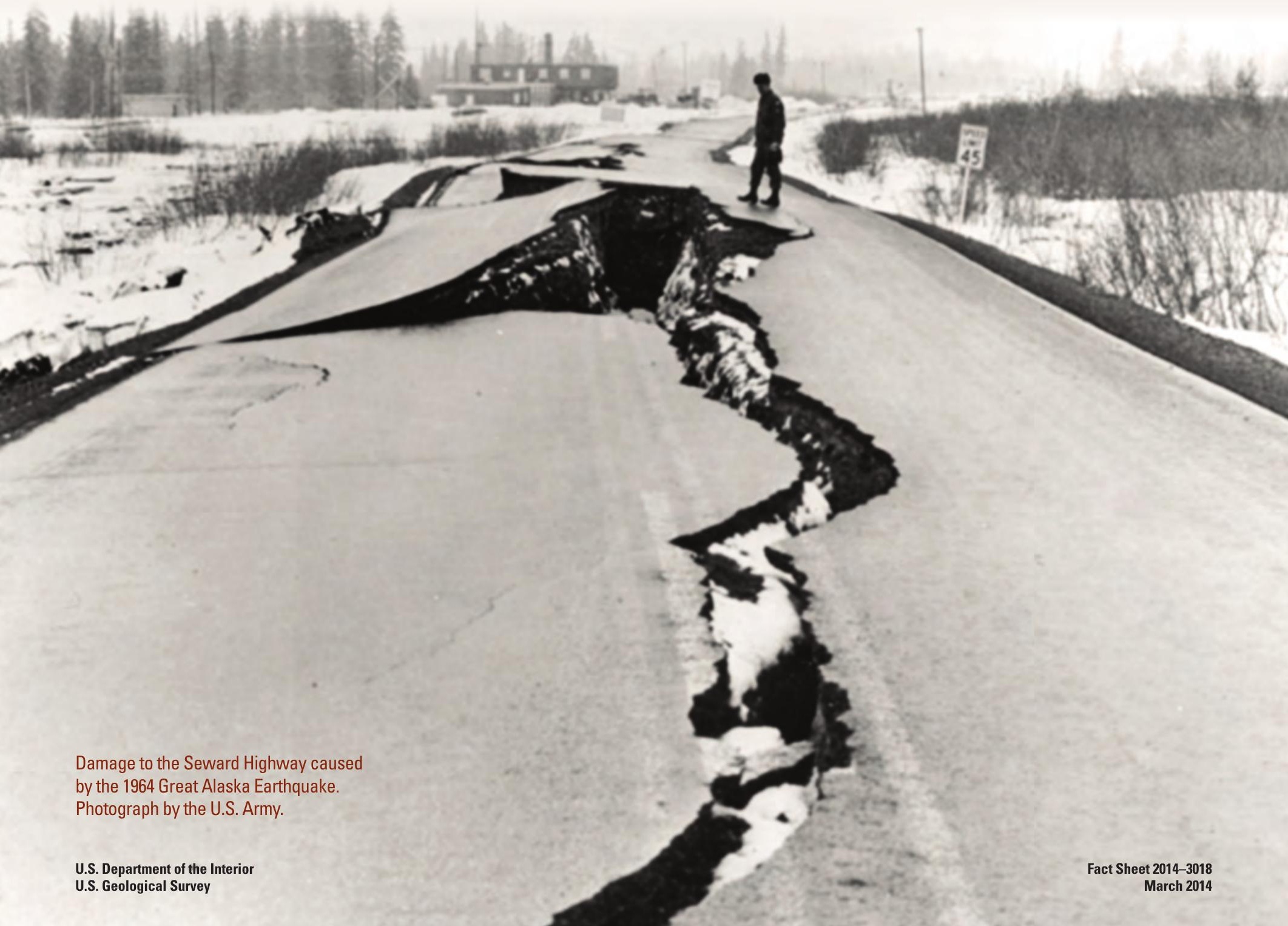




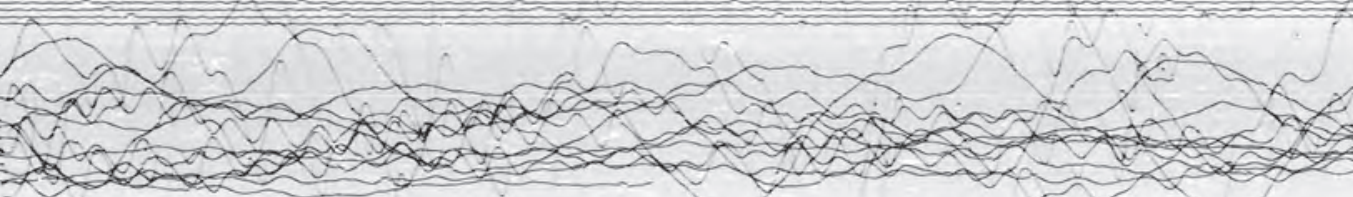

\section{Scientific Impact of the Great Alaska Earthquake}

\section{Support for the Theory of Plate Tectonics}

At first, geologists did not know how such a huge earthquake could have happened, because the prevailing theories of the day could not explain such a large movement. So they examined the earthquake within the framework of a new theory, plate tectonics, which proposed that the crust of the Earth consists of about a dozen or so major sections, or plates, that sit on top of the hot mantle below and slowly move past each other or collide. Compelling evidence for this theory is that most earthquakes occur near the boundaries of these plates, and the plates' movements through geologic time help to explain many of the landforms and processes that we observe on Earth.

Earth scientists now recognize that the 1964 Great Alaska Earthquake resulted from plate convergence: where the Pacific Plate is being overridden by the

Map of southern Alaska showing the epicenter of the 1964 Great Alaska Earthquake (red star), caused when the Pacific Plate lurched northward underneath the North American Plate. There was extensive damage to coastal towns and infrastructure throughout the region, particularly in Anchorage, Seward, Whittier, and Valdez. Widespread uplift occurred seaward of Kodiak Island and the Kenai Peninsula, while subsidence occurred inland as a result of the magnitude 9.2 earthquake. In 1964, there were no instruments in Alaska capable of recording the earthquake, but now there is an extensive network of stations (yellow squares) that monitor the seismically active plate boundary along the Aleutian Trench.
North American Plate, it descends, or subducts, into the Earth's mantle along the Aleutian Trench. Subduction zones like southern Alaska's occur throughout the world, and the 1964 Alaska earthquake was the first to be generally understood by earth scientists as having occurred on a subduction zone interface: the slip was along the gently dipping boundary, or "megathrust fault," between the denser downgoing oceanic plate and the lighter overriding continental plate. Since 1964, subduction zones have been recognized elsewhere, including Indonesia, Japan, and Chile, where great earthquakes have also occurred during the past 60 years. The understanding gained from the 1964 Great Alaska Earthquake provided the geological framework for assessing the earthquake and tsunami hazards at all convergent margins

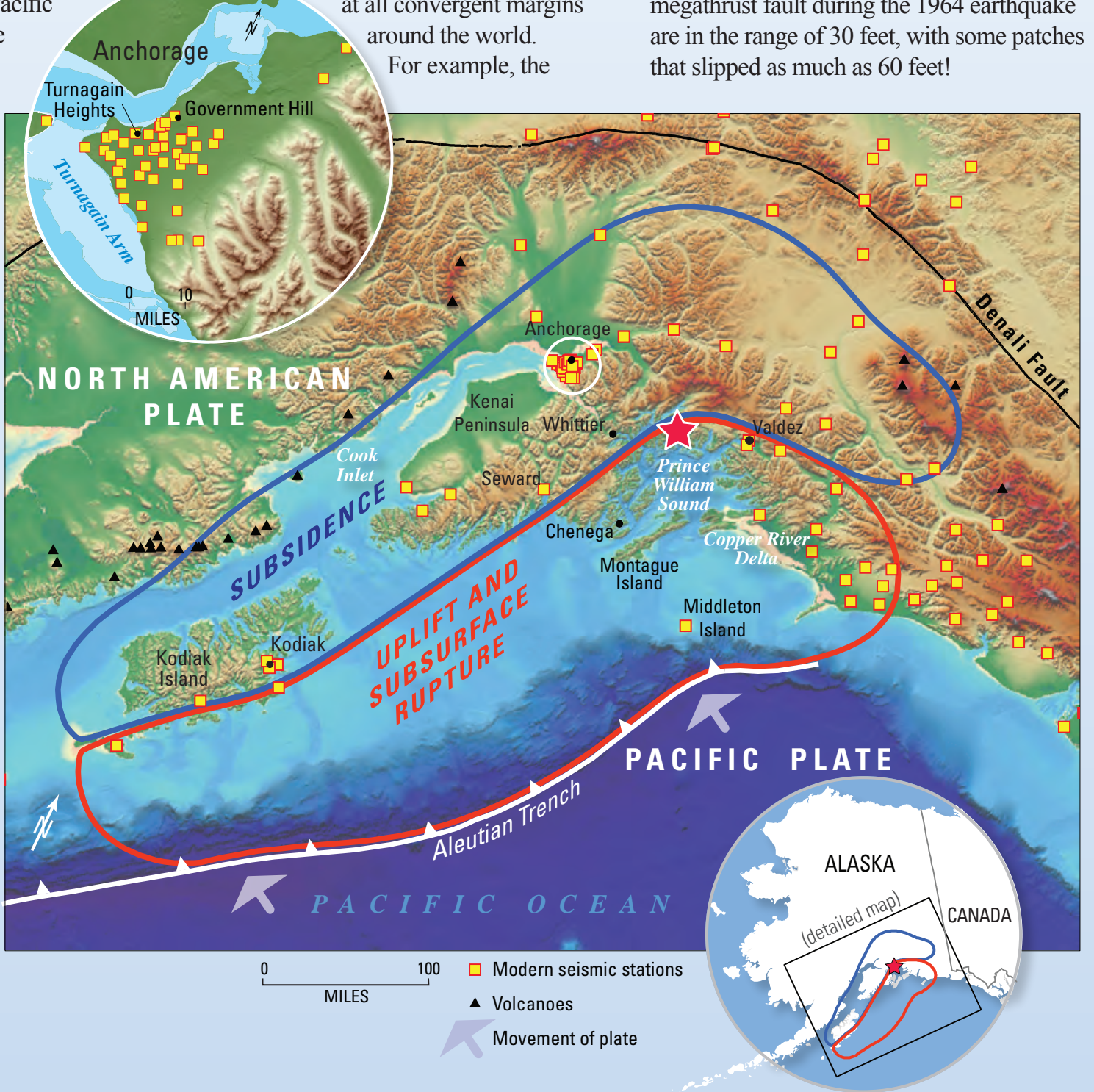




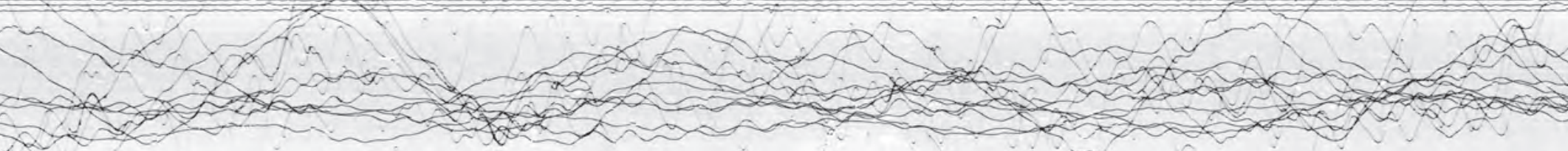

Seismogram of 1964 Great Alaska-Earthquake from station in Weston, Massachusetts. Each line is 30 minutes. Image courtesy of IRIS Data Management System.

\section{Observation and Explanation of Earthquake Ground Deformation}

Geologists from the U.S. Geological Survey (USGS) were the first earth scientists to respond to the devastated region, and they mapped land-level changes resulting from the 1964 earthquake all along the coast of southern Alaska. They were astonished to find that the earthquake was accompanied by vertical shifts of the Earth's surface over an area two-thirds the size of California. Parts of the coast sank, or subsided, as much as 8 feet, and other parts rose by as much as 38 feet. In addition, geodetic surveys showed that much of coastal Alaska moved seaward at least 50 feet. The uplift and subsidence data from the 1964 earthquake have been repeatedly used to test models of how subduction zones rupture during great earthquakes and to calculate how much the plates shifted along the fault plane at depth.

It is now recognized that major subduction-zone earthquakes produce a pattern of uplift of the coastline above the shallowest and most seaward part of a rupture, and that subsidence of the coastline occurs farther inland from the rupture. This pattern gradually reverses over a period of decades to centuries as continuing plate motion restores the Earth's surface to its pre-earthquake state. This cyclic pattern was first revealed in the studies following the 1964 earthquake.
In areas experiencing initial sudden subsidence, such as Cook Inlet and much of Kodiak Island, coastal forests and peaty marsh deposits dropped below sea level and were killed by the sudden inundation by salt water. These drowned forests become buried by marine silt, and, in some places, by tsunami sand deposits. During the gradual uplift that follows, salt-water-tolerant peat eventually accumulates on the marine silt, and new forests grow on the peat. In other places, such as the Copper River Delta, located closer to the Aleutian Trench, sudden uplift occurs first, followed by slow submergence between earthquakes.

Sediment cores collected through these cyclic uplift/subsidence deposits have yielded an unprecedented 5,600-year-long record of great earthquakes along the southern Alaska coast. In the Copper River Delta, the cores show evidence of 9 prehistoric earthquakes, implying an average interval of about 600 years between 1964-type great earthquakes in southern Alaska. Other studies to the west of the Copper River Delta, in the Turnagain Arm and in the Kodiak Island area, show that the last 1964-type earthquake may have occurred 880 years ago and that the average interval between great earthquakes is about 535 years.

Middleton Island, located offshore southern Alaska, was uplifted about 10 feet by the 1964 earthquake, and a new wavecut terrace was formed. The observation of this new landform led to subsequent USGS study of a series of five other wave-cut terraces that were first noticed on the island in 1933 but were not originally recognized as earthquake-related features. Geologists realized that each terrace had been formed by uplift during a great 1964-type earthquake. Radiocarbon dating of fossil driftwood from beach deposits on these older terraces showed that the repeat times for these prior earthquakes ranged from 400 to 1,200 years, with an average of 800 years. Since the 1964 earthquake, similar wave-cut terraces have been recognized and used in other subduction zones to better assess the hazards and earthquake recurrence intervals associated with them.

The movement of the Pacific Plate northward beneath the North American Plate resulted in subsidence in some areas and uplift in others. Whale Bay, on Prince William Sound (inset), rose nearly 10 feet, but a roadway on the Kenai Peninsula sank beneath sea level and was washed out. Both USGS photographs by George Plafker.

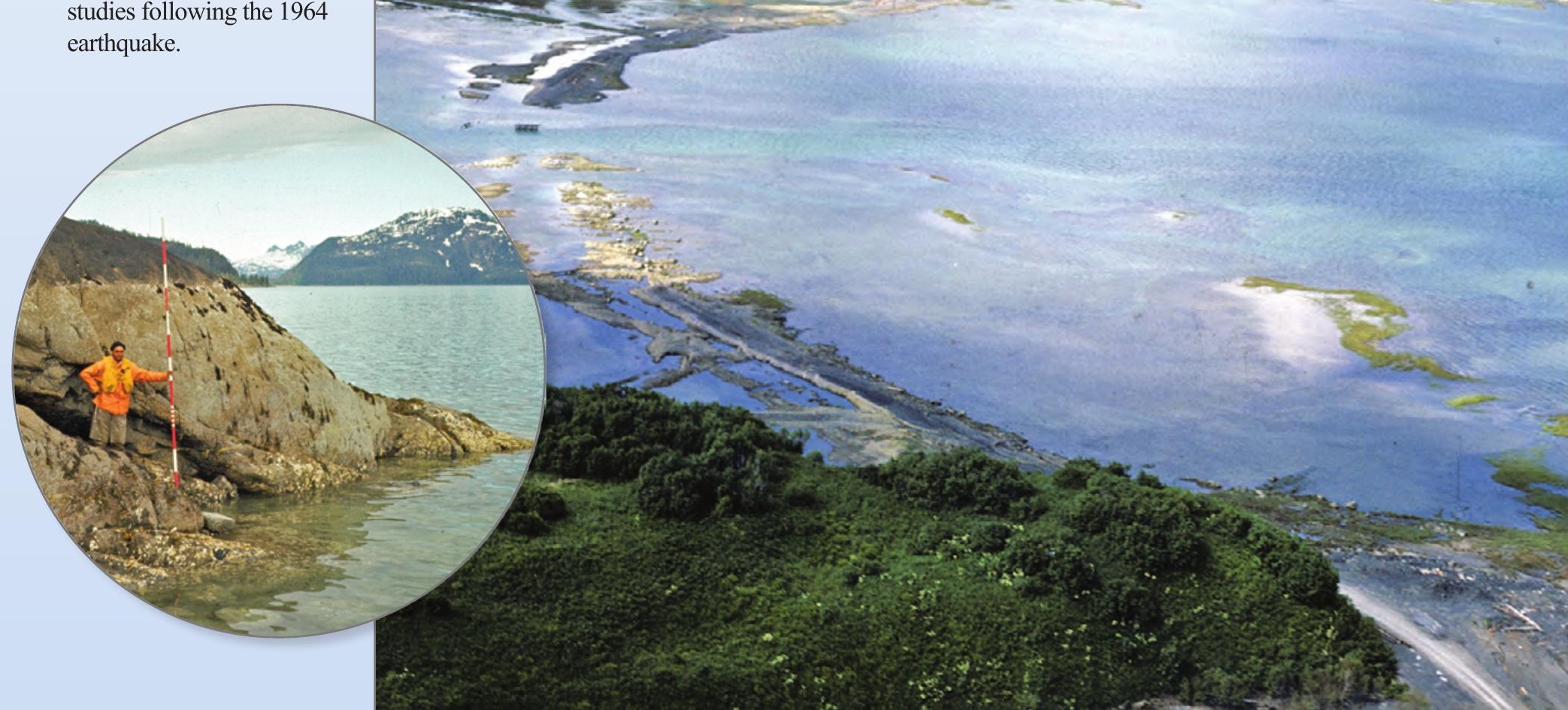





\section{Increased Understanding of Earthquake Hazards in Alaska and Elsewhere}

The understanding of the characteristics of subduction zones, and the earthquakes and tsunamis such zones produce, dates largely from the 1964 Great Alaska Earthquake. Geologists are thus able to identify the hazards posed by great subduction-zone earthquakes in areas where they have not occurred recently, or even in historical times, like the Cascadia subduction zone (along the coast of British Columbia, Washington, Oregon, and northern California). Identifying these hazards in advance will help reduce losses in future great earthquakes.

Since the 1964 Great Alaska Earthquake, scientists at the USGS and elsewhere have used Global Positioning System (GPS) receivers to accurately measure the rate at which the Pacific Plate is converging with southern Alaska, as well as the rate of motion along crustal faults in southern Alaska. These measurements show that the Pacific Plate is sliding beneath southern Alaska at an average rate of 2.3 inches per year. The plates move in a stick-slip motion with strain accumulating on the Aleutian subduction zone when it is stuck, and strain is suddenly released when the subduction zone slips, causing an earthquake. GPS measurements also show that this plate convergence compresses the crust of southern Alaska, pushing it out to the west along faults with horizontal (lateral) offsets such as on the Denali Fault, which

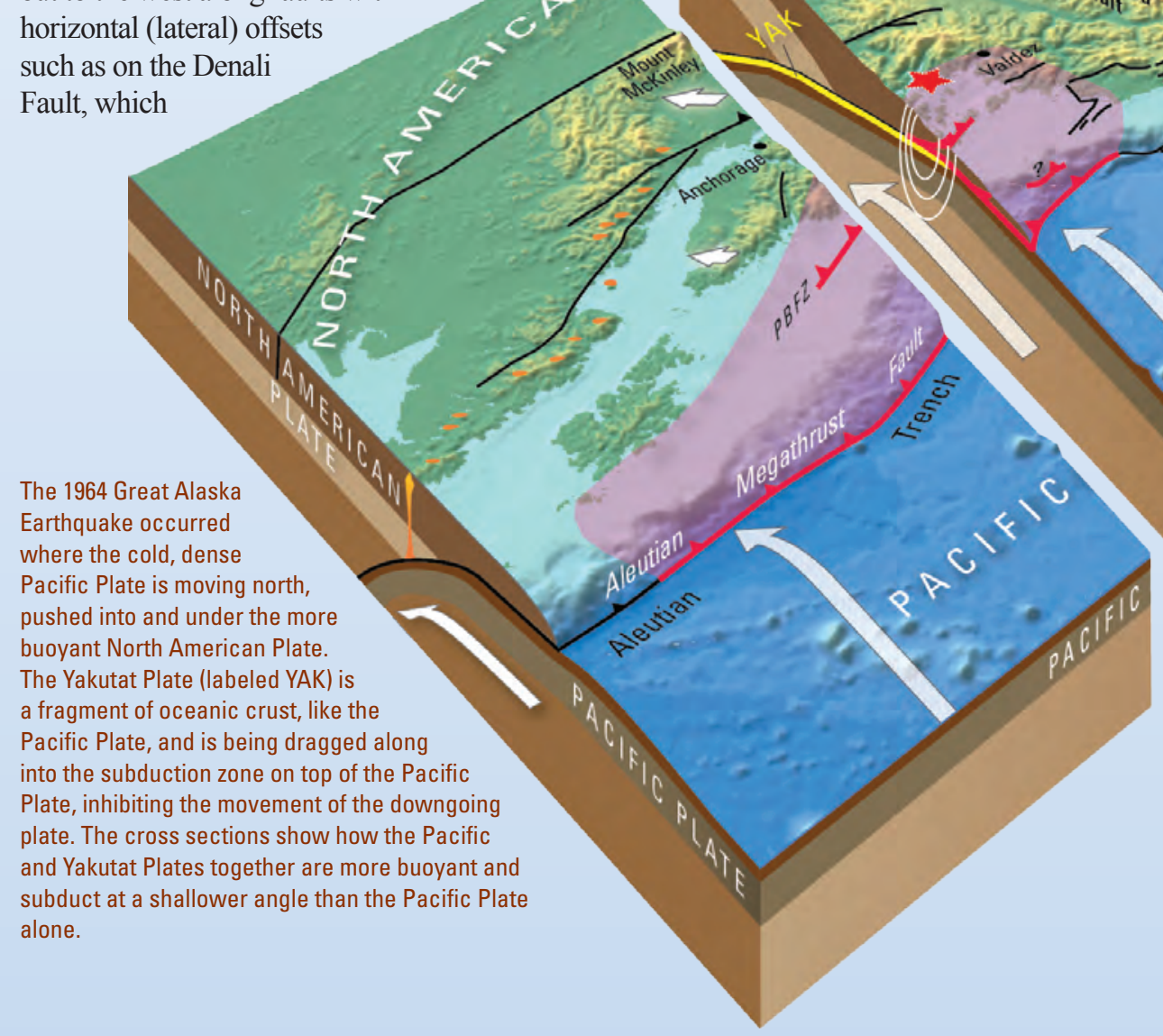

harbors. Sixteen people died and the coasts and estuaries of the U.S. west coast sustained millions of dollars in damage. Such destruction from such a faraway earthquake provided motivation for the development of West Coast/Alaska Tsunami Warning Center (now called the National Tsunami Warning Center), operated by the National Oceanic and Atmospheric Administration, which uses earthquake data supplied by the USGS. Tsunami warning centers can now send alerts within minutes of an earthquake that has the potential for generating a tsunami. Although this system works well for tsunamis that travel across the ocean, it is too slow to provide significant warning time for tsunamis generated by local splay-fault ruptures and submarine landslides. For these local tsunamis, the strong shaking produced by the earthquake serves as the tsunami warning. Tsunami risk is also mitigated by mapping tsunami inundation zones, planning evacuation routes, educating coastal communities and their visitors, constructing tsunami-resistant infrastructure, and creating earthquake monitoring and tsunami warning systems and centers, all of which have been completed and are regularly updated for

the U.S. west coast and other areas where tsunamis may occur. 


\section{Effects of the Earthquake}

Survivors of the 1964 Alaska earthquake will never forget the strong shaking that lasted for as much as four and a half minutes when a 580-mile section of the fault plane ruptured. One Anchorage resident recorded his observations throughout the earthquake, describing shaking at his residence that lasted for four minutes. The long duration of the movement led to significant ground failures, slumping, landsliding, and liquefaction in the Anchorage area. Massive landslides were triggered in and near downtown Anchorage and Government Hill, as well as in the Turnagain Heights residential area. Water and gas mains, as well as sewer, telephone, and electrical systems were disrupted throughout Turnagain Heights owing to landslides.

In southern Alaska, where the loss of life was largest, 70 percent of the fatalities resulted from tsunamis generated by massive submarine landslides that occurred on steep slopes of the seafloor. Because of the proximity of many of these submarine landslides to coastal communities, the tsunamis they created reached landfall within a few minutes of the start of ground shaking and inundated some areas as much as 170 feet above sea level. The coastal communities of Whittier, Valdez, and Seward were hit particularly hard by these locally caused tsunamis. Chenega, a small village in Prince William Sound, lost 23 people - a third of its population - when a 65-foot wave arrived about four minutes after the earthquake. These sobering facts show that residents of any coastal community need to immediately head to higher ground when they feel seismic shaking.

\section{Enduring Legacies}

In 1964, no instruments capable of recording the strong ground motions produced by the Great Alaska Earthquake were located in southern Alaska. Since then, in cooperation with the State of Alaska, the USGS has installed an extensive earthquake-monitoring network as part of the Advanced National Seismic System. (For more information, see Fact Sheet 075-00, http://pubs.usgs.gov/fs/2000/fs075-00/.)

Such recordings provide data seismologists need to assess shaking hazards during future earthquakes, and are used to prepare the USGS National Seismic Hazard Maps (http://pubs. usgs.gov/fs/2008/3017/) and ShakeMaps, which show the distribution and severity of earthquake ground motion. Using ShakeMaps and a comprehensive worldwide population database, the USGS now makes rapid estimates of the expected fatalities and economic losses from large earthquakes around the globe using a system called PAGER, or Prompt Assessment of Global Earthquakes for Response (see Fact Sheet 2010-3036, http://pubs.usgs.gov/ $\mathrm{fs} / 2010 / 3036 /)$. The ground-motion data from more recent events are also used by the engineering community to design buildings and other structures to resist earthquake shaking, helping to minimize loss of life and property.

The scientific observations and interpretations of the 1964 Great Alaska Earthquake are preserved in publications for use by future generations. The USGS published the results of its comprehensive study of the 1964 earthquake in a series of six Professional Papers (available at http://earthquake.usgs.gov/earthquakes/ alaska1964/) that document geologic, seismologic, and hydrologic observations following the earthquake, as well as earthquake- and tsunamirelated damage to infrastructure and Alaska communities. The data continue to be used on a daily basis for land-use planning as well as

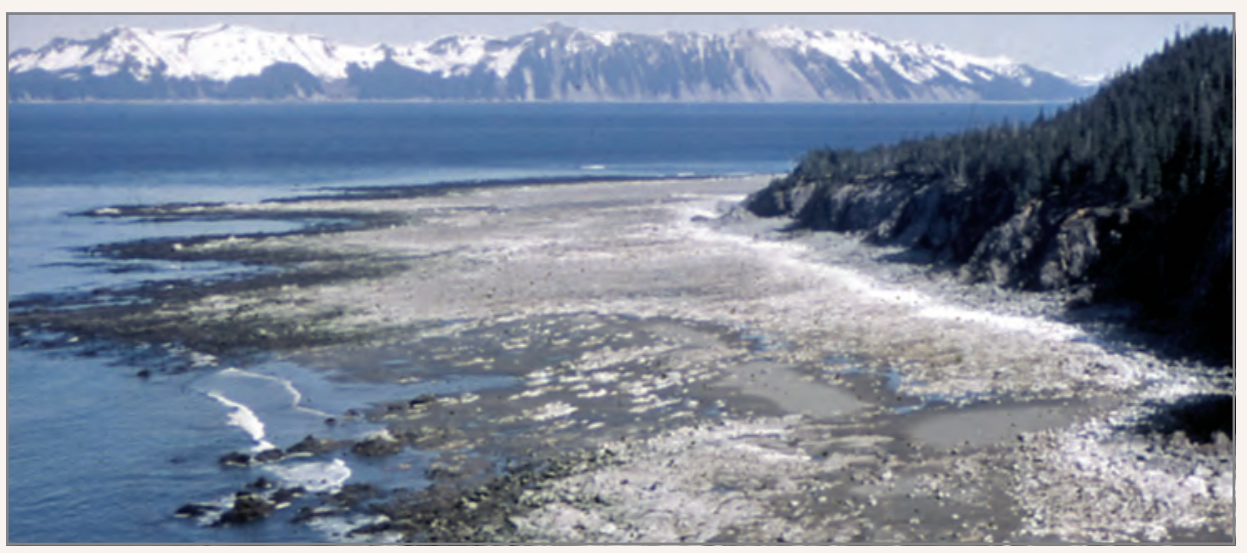

Cape Cleare on Montague Island was uplifted 33 feet during the 1964 Great Alaska Earthquake, creating the new terrace shown here. The white coating on the rocks - about a quarter of a mile wide-is the remains of marine microorganisms that were desiccated when the seafloor was uplifted out of the water. On the mountains in the background, light gray patches are landslides triggered by ground shaking. Photo at top right shows ground failure and damage to homes in the Turnagain Heights area of Anchorage, Alaska. USGS photographs by George Plafker.

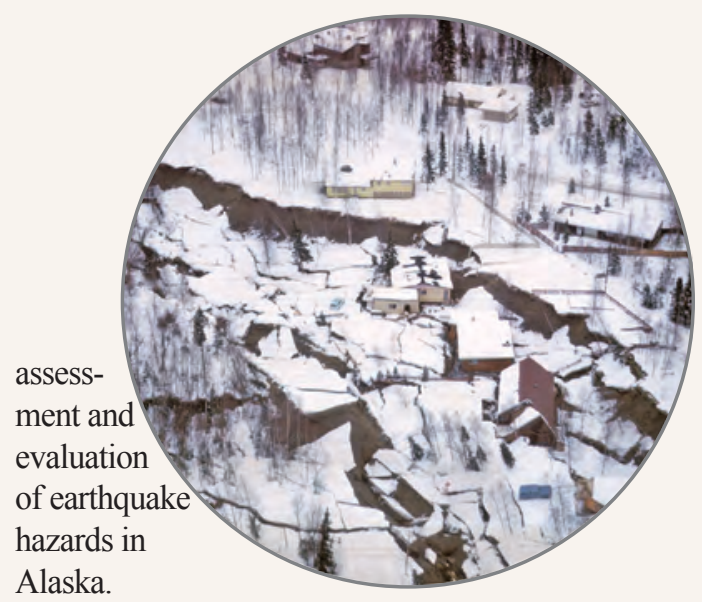

The establishment of the USGS

National Center for Earthquake Research in 1964 brought together the USGS earthquake expertise into a single point of focus, and it became a cornerstone of the USGS Earthquake Hazards Program, in turn a major element of the National Earthquake Hazards Reduction Program (NEHRP). Under the direction of the NEHRP, the USGS protects life and property by monitoring earthquakes nationally and internationally, making seismic-hazard assessments used in building codes and for other purposes, conducting research in earthquake occurrence and physics, and performing outreach and education on earthquake phenomena and hazards.

\section{Additional Resources}

The Great Alaska Earthquake and Tsunami, USGS Earthquake Hazards Program: http://earthquake.usgs.gov/earthquakes/ alaska1964/

Earthquake Preparedness Guide, Alaska Earthquake Information Center: http://www.aeic.alaska.edu/html_docs/nextbigeq.html

"Magnitude 9.2," video by the USGS:

http://www.youtube.com/watch?v=jvl-4IWjH Xo\&list=UUeXH8GZyV3sVqAr45AvupOA $\&$ feature $=$ share \&inde $x=3$

Thomas M. Brocher, John R. Filson, Gary S. Fuis, Peter J. Haeussler, Thomas L. Holzer, George Plafker, and J. Luke Blair

Edited by Claire M. Landowski Graphic design by Jeanne S. DiLeo

Earthquake Science Center U.S. Geological Survey

Menlo Park, CA 94025

http://earthquake.usgs.gov; Earthquake Information Hotline: (650) 329-4085

This Fact Sheet and any updates to it are available online at

http://pubs.usgs.gov/fs/2014/3018/ ISSN 2327-6932 (online); ISSN 2327-6916 (print) http://dx.doi.org/10.3133/fs20143018 